\title{
ОЦНКА СИТУАТИВНОГО КОПІНГУ ЯК СКЛАДОВОЇ ПСИХОЛОГІЧНОГО ЗДОРОВЯ СТУДЕНТІВ СПОРТИВНОГО ПРОФІЛЮ ЗАКЛАДІВ ВИЩОЇ ОСВІТИ В ПЕРІОД ЕКЗАМЕНАЦІЙНОЇ СЕСІЇ
}

\author{
Ляменко Валентина ${ }^{I A B C D}$, Гачуко Олена ${ }^{I C D}$, Гнутова Наталія ${ }^{I C D}$ \\ 1Київський Університет імені Бориса Грінченка, Київ, Україна
}

Внесок автора: А - дизайн дослідження; В - збір даних; C - статистичний аналіз;

$\mathrm{D}$ - підготовка рукопису.

\begin{abstract}
Анотація
Мета - визначення пріоритетних копінг-стратегій у студентів, які навчаються на освітніх програмах спортивного профілю, третього та п’ятого курсу до екзаменаційної сесії, під час та після іiі закінчення.

Матеріали. У дослідженні брали участь студенти третього та п’ятого курсу, факультету здоров'я, фізичного виховання і спорту, які дали згоду на проведення психологічного тестування. Віковий діапазон досліджуваних студентів $19-23$ роки. Кількість - 80 осіб. Застосовувалася «Анкета оцінки копінг-стратегій» С. Карвера.

Результати. Отримано дані за результатами тестування по наступним шкалам: активний копінг, планування, пошук активної громадської підтримки, пошук емоційної громадської підтримки, придушення конкуруючої діяльності, звернення до релігії, позитивне тлумачення і зростання, стримування, прийняття, фокус на емоціях і їх вираження, заперечення, ментальне відсторонення, поведінковий відсторонення, використання алкоголю і наркотиків, гумор.

Висновки. У студентів третього курсу переважає активний копінг, пошук соціальної підтримки, планування, а у студентів п’ятого курсу - звернення до релігії, фокус на емоціях, позитивне трактування і зростання.
\end{abstract}

Ключові слова. ситуативний копінг, копінг-стратегія, студент, стратегії поведінки.

\section{Вступ}

Стрес є невід'ємною частиною життя сучасної людини. Завдяки йому відбувається пристосування людини до умов зовнішнього середовища, що здійснюється за рахунок універсального комплексу нейрогуморальних реакцій. Проте, сучасне розуміння теорії стресу відійшло від суто біологічного і носить міждисциплінарний характер. Відповідно для сучасної психології проблема стресу та вивчення його специфіки, ролі та наслідків для різних сфер життя людини $\epsilon$ актуальною. Особливої уваги в цьому контексті потребує як сфера вищої освіти загалом, так і студентство зокрема. Дана категорія, об’єднуючи різновіковий контингент людей, яких можна диференціювати за рівнем інтелектуальних здібностей, особистісними особливостями, соціальним становищем, віковим критерієм $€$ такою, що найбільше піддається різноманітним видам стресу (емоційним, інтелектуальним, фізіологічним) $[6,7,10]$.

Як зазначають Ю. Щербатих і А. Фаустов, навчальна діяльність студентів має ряд специфічних особливостей, притаманних лише цій формі розумової діяльності, таких як: одночасне спостереження за кількома процесами, що змінюються у часі, або вивчення багатьох предметів за короткий відрізок часу; систематичне та швидке переключення з одного об'єкта чи предмета на інший, постійна переадаптація; сприймання та переробка різноманітної інформації у великому обсязі, яка часто має емоційний характер; гострий дефіцит часу для переробки цієї інформації та для прийняття відповідальних рішень; відчуття підвищеної відповідальності за рішення, що приймаються, й швидке виникнен- 
ня стану нервово-психічної напруги; виконання значної частини роботи у вечірній і нічний час; мала участь апарату рухового аналізатора [5].

Як зазначає Турчак О. М. усі ці фактори самостійно здатні викликати психічне перевантаження студентів, а, отже, і зумовлювати ситуації емоційної напруги. Як наслідок, працездатність студентів знижується, що відбивається на їхній успішності. Саме тому необхідними є дослідження природи виникнення емоційної напруги у навчальній діяльності студентів, зокрема ситуацій, які їі зумовлюють [17].

Навчальні або академічні стреси у студентів досліджували S. Agarwal, L. Cheng, L. Cohen, G. D. Marshall, Q. Wei, P. Wong, Б. Ананьєв, Д. Андрєєва, В. Бодров, О. Бондаренко, О. Варес, Н. Горст і В. Горст, І. Ссауленко, Л. Китаєв-Смик, Л. Ковальова, М. Коврова, Б. Коган, І. Коровайко, Н. Наєнко, Н. Пейсахов, М. Плеханова, В. Пономаренко, М. Расулова, Ю. Сосновікова, О. Фаустов, С. Федорова, В. Шарай, Ю. Щербатих та ін. Відомо, що стрес - $\epsilon$ природною реакцією людини на ситуацію загрози, небезпеки, дискомфорту. Його призначення - мобілізувати всі ресурси організму для подолання перешкод, вирішення проблем, виконання важливих завдань і в результаті забезпечити успішну адаптацію до умов середовища. Стресові реакції допомагають людині бути зібраною, сконцентрованою, проявляти підвищену активність, дозволяють задіяти всі інтелектуальні, емоційні та вольові ресурси.

Період отримання вищої освіти є один із найбільш стресових у житті людини, а найстресогеннішими факторами навчальної діяльності, безумовно є екзамени, заліки, захисти дипломних робіт. Тому період сесії для більшості студентів сповнений стресами різного характеру, таких як фізіологічний (недосипання, головні болі); інформаційний (надмірна завантаженість інформацією з різних навчальних дисциплін), емоційного та соціального (невдоволення собою порівняно з більш успішними одногрупниками). Тому ми вважаємо, що вивчення факторів, які дозволять уникнути стресів під час сесії, $є$ актуальним та перспективним.

Метою дослідження $\epsilon$ визначення пріоритетних копінг-стратегій у студентів, які навчаються на освітніх програмах спортивного профілю, третього та п’ятого курсу до екзаменаційної сесії, під час та після ії закінчення.

\section{Методи}

Дослідження проводилося на базі Київського університету імені Бориса Грінченка. У дослідженні приймали участь студенти третього та п'ятого курсу, факультету здоров'я, фізичного виховання і спорту, які дали згоду на проведення психологічного тестування. Віковий діапазон досліджуваних студентів $19-23$ роки. Кількість - 80 осіб. Застосовувалася «Анкета оцінки копінг-стратегій» С. Карвера (в адаптації I. Дементій). [17]. Результати було оброблено у відповідності з ключем до тесту. На основі аналізу показників складено порівняльні діаграми ведучих копінг-стратегій у студентів третього та п’ятого курсу.

\section{Результати}

Для оцінки ситуативного копінга (реакцію на окрему ситуацію чи реакцію в даний момент часу), тобто визначення стратегій поведінки, які вибирають студенти до, під час і після ситуації оцінювання, була застосована «Анкета оцінки копінг-стратегій» С. Карвера (в адаптації I. Дементій), яка включає 15 шкал: активний копінг (1), планування (2), пошук активної громадської підтримки (3), пошук емоційної громадської підтримки (4), придушення конкуруючої діяльності (5), звернення до релігії (6) , позитивне тлумачення і зростання (7), стримування (8), прийняття (9), фокус на емоціях і їх вираження (10), заперечення (11), ментальне відсторонення (12), поведінковий відсторонення (13), використання алкоголю і наркотиків (14), гумор (15).

Усвідомлюючи, що специфіка ситуації в більшій мірі може визначати особливості поведінки людини, відправною точкою нашого дослідження виступило вивчення соціально-ситуативного контексту оволодіння через визначення змістовних характеристик, кола і рівня стрессогенності ситуації оцінювання. Тепер звернемося до обговорення результатів, що підтверджують «поведінкову» схожість ситуацій оцінювання, через аналіз особливостей стратегій їх подолання суб'єктом.

Результати, отримані за допомогою «Анкети оцінки копінг-стратегій» С. Карвера (в адаптації I. Дементій), дозволяють стверджувати, що до сесії в якості переважаючих копінг-стратегій у студентів третього курсу виступає активний копінг, пошук соціальної підтримки, планування, 
а у студентів п’ятого курсу - звернення до релігії, фокус на емоціях, позитивне трактування i зростання (рис. 1), що свідчить про вікову динаміку в використанні копінг-стратегій.

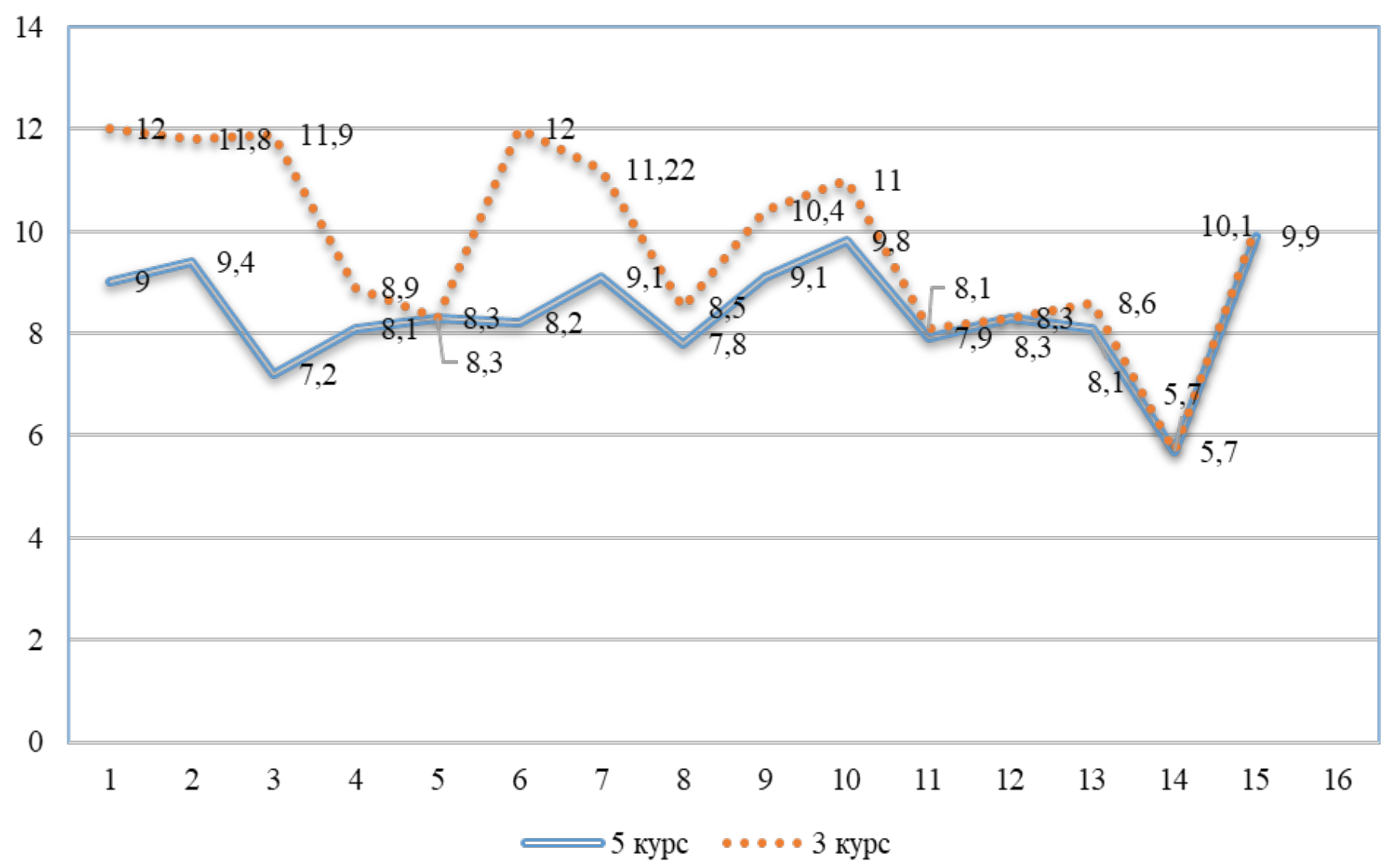

Рис.1. Результати дослідження за «Анкетою оцінки копінг-стратегій» К. Карвера (до сесії)

Вибір копінга залежить від багатьох факторів. По-перше, від особистості суб'єкта і особливостей ситуації, що детермінують копінг-поведінку. По-друге, від соціальних, культурних, статевих та інших особливостей. На наш погляд, вибір саме таких стратегій як оптимальних визначається особливостями екзаменаційної ситуації. Так, передекзаменаційний період включає дії і операції, спрямовані на пошук необхідної інформації, їі усвідомлення, засвоєння, що вимагає від студента підвищеної активності як поведінкової, так і психічної та когнітивної.

Активний копінг обумовлений певними діями та зусиллями, спрямований на те, щоб усунути або обійти джерело стресу. Фокус на емоціях спрямований на тимчасову розрядку напруги, яке закономірно виникає в період інтенсивної взаємодії з ситуацією, відрізняється підвищеною суб'єктивною значущістю і стресогенністю. Пошук емоційної громадської підтримки дозволяє знизити екзаменаційну тривожність і нормалізувати емоційний стан, необхідний для здійснення когнітивної діяльності за рахунок допомоги, інформації або суттєвої поради від оточуючих його людей.

Високий статус обраної студентами стратегії позитивного трактування і зростання можна пов'язати з наявністю великого досвіду участі в екзаменаційних ситуаціях, спрямованих в ціло-

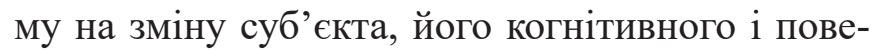
дінкового розвитку і як і в більшості випадків обумовленого процесом підготовки до іспиту і очікуванням його результатів.

Звернення до релігії спрямоване на уникнення взаємодії з реальністю. Воно супроводжується більш активною участю в релігійній діяльності. Планування - думки про те, як протистояти джерела стресу - це планування спроб активного копінга. Досить сильно вираженою стратегією студентів третього і п'ятого курсу є використання алкоголю (37,5\%). Це, на жаль, є надзвичайно негативним соціальним зрушенням теперішнього часу, яке широко обговорюється в сучасній психологічній літературі. 
Під час сесії студенти третього і п’ятого курсів використовують майже однакові стратегії поведінки, як і в передекзаменаційний період, тобто третьокурсники: активний копінг, пошук громадської підтримки, планування; п'ятикурсники: звернення до релігії, фокус на емоціях, позитивне трактування і зростання. Але, на відміну від до екзаменаційного періоду, під час сесії рівень показників значно підвищився $(+26 \%)$.
Студенти третього курсу застосовують більш активні поведінкові стратегії, при яких вони прагнуть використовувати всі наявні особистісні ресурси для пошуку можливих способів ефективного вирішення проблеми; а студенти п'ятого курсу, хоча також вибирали активні поведінкові стратегії, однак вони спрямовані на ефективне вирішення проблеми за допомогою змін у собі та на тимчасову розрядку напруги, викликану стресовою ситуацією (рис. 2).

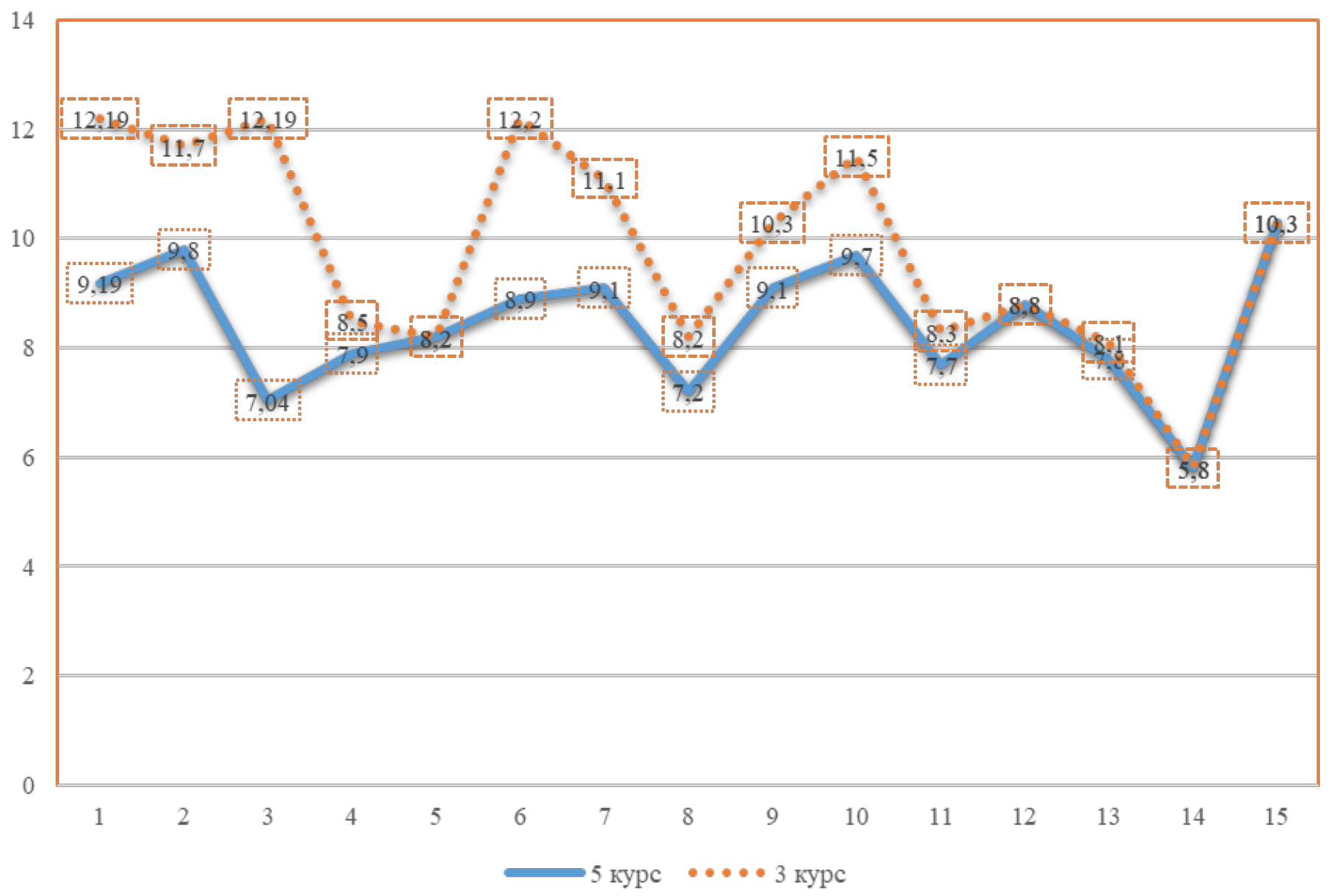

Рис 2. Результати дослідження за «анкетою оцінки копінг-стратегій» С. Карвера (підчас сесії)

Такий вибір копінг-стратегій може бути обумовлений тим, що ми досліджуємо ситуацію, та особистість, яка вже обрала певну копінг-поведінку і намагається дотримуватися іiі.

Після екзаменаційного періоду досліджувані вибирали зовсім інші стратегії поведінки, ніж до або під час екзаменаційного періоду. Відмінність полягала в рівні вираженості стратегій поведінки. Так, обиралися такі стратегії: позитивне трактування і зростання (студенти третього курсу - 12,19, студенти п'ятого курсу - 9, 19); стримування (студенти третього курсу 12,19 , студенти п'ятого курсу - 7,04); прийняття (студенти третього курсу - 11,62, студенти п'ятого курсу - 9,59). Такі результати дослідження можуть свідчити про те, що після закінчення екзаменаційного періоду студенти як третього, так і п'ятого курсу знаходять користь у даній ситуації через особисте зростання або розглядають іiї в більш сприятливому баченні (рис. 3). 


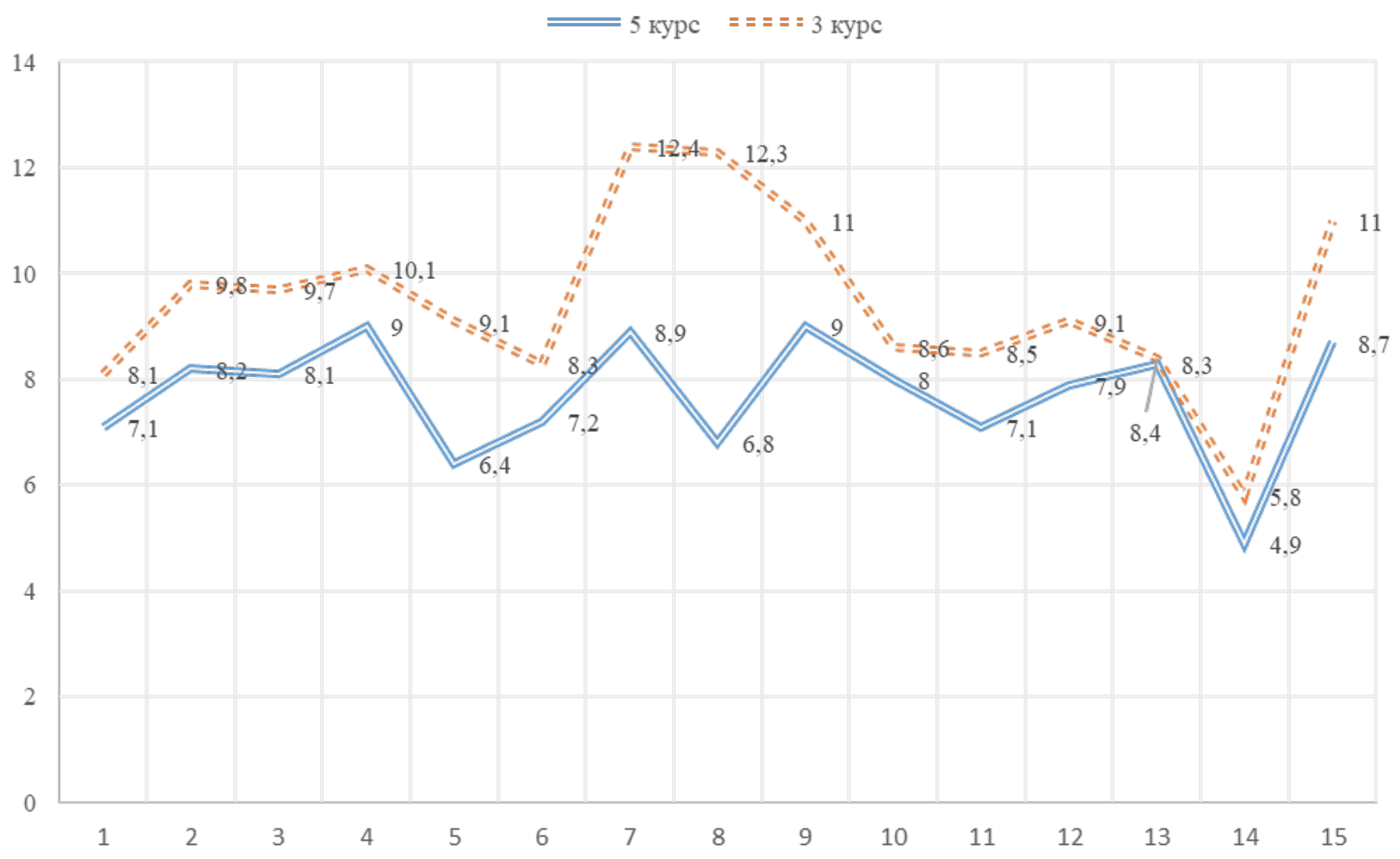

Рис.3. Результати дослідження за «анкетою оцінки копінг-стратегій» С. Карвера (після сесії)

Отже, можна стверджувати, що при зіткненні з важкими ситуаціями, особистість орієнтується на їх вирішення застосовуючи різні стратегії копінг-поведінки, такі як активний копінг, позитивне трактування і зростання, пошук активної громадської підтримки, стратегія поведінкового відсторонення, відмови, вживання алкоголю.

\section{Висновки}

Зважаючи на те, що екзаменаційна сесія $\epsilon$ важкою стресогенною ситуацією, яка вимагає від студентів мобілізації внутрішніх і зовнішніх ресурсів як задля опанування самої ситуації, так і пристосування до зрушень в організмі та психіці, зумовлених екзаменаційним стресом, у студентів, факультету здоров'я, фізичного виховання і спорту, є особисті копінг-стратегії, які допомагають їм в даному випадку. У студентів третього курсу переважає активний копінг, пошук соціальної підтримки, планування, а у студентів п’ятого курсу - звернення до релігії, фокус на емоціях, позитивне трактування і зростання.

Конфлікт інтересів. Автори заявляють, що не існує конфлікту інтересів.

\section{References}

1. Chelyshkova TV, Khasanova NN, Grechishkina SS. Features of functional state of the central nervous system of students in the course of educational activity. Vestnik AGU. Seriya "Yestestvennomatematicheskiye i tekhnicheskiye nauki». 2008; 9: 69-75.

Челышкова ТВ, Хасанова НН, Гречишкина СС. Особенности функционального состояния центральной нервной системы студентов в процессе учебной деятельности. Вестник АГУ. Серия
«Естественно-математические и технические науки». 2008; 9: 69-75.

2. Dolinska L, Matyash-Zayats L. Presentation of modern youth about the features of interpersonal conflicts. Socio-psychological dimension of democratic transformations in Ukraine. Ukrayins'kyy tsentr politychnoho menedzhmentu. 2003; 331-338.

Долинська Л, Матяш-Заяц Л. Уявлення сучасної молоді про особливості міжособистісних кон- 
фліктів. Соціально-психологічний вимір демократичних перетворень в Україні. Український центр політичного менеджменту. 2003; 331-338.

3. Dwyer A. Cummings AL. Stress, self-efficacy, social support, and coping strategies in university students. Canadian Journal of Counseling. 2001; 35: 208-220.

4. Eisenbarth C. Coping profiles and psychological distress: a cluster analysis. North American Journal of Psychology. 2012; 14: 485-496.

5. Faustov AS, Shcherbatykh SE. Education and health. Voronezh; 2000. 32 p. Фаустов АC, Щербатых ЮВ. Обучение и здоровье. Воронеж; 2000. $32 \mathrm{c}$.

6. Fedorova YV. The stress of that role in the first part of the student. Problemy suchasnoyi pedahohichnoyi osvity. Pedahohika i psykholohiya. 2013; 39(4): 290-294.

Федорова ЯВ. Стрес та його роль в навчальній діяльності студента. Проблеми сучасної педагогічної освіти. Педагогіка і психологія. 2013; 39(4): 290-294.

7. Frymier $\mathrm{AB}$, Houser ML. The teacher-student relationship as an interpersonal relationship. Communication Education. 2000; 207-219.

8. Kupriyanov RV. Psychodiagnosis of stress: a workshop. Kazan: KNITU; 2010. 212 p.

Куприянов РВ. Психодиагностика стресса: практикум. Казань: КНИТУ; 2010. 212 с.

9. Laybourne AH, Biggs S, Martin FC. Predicting habitual physical activity using coping strategies in older fallers engaged in falls-prevention exercise. Journal of Aging and Physical Activity, 2011; 19: 189-200.

10. Lisenko-Gelemb'yuk KM. The psychological incentive of self-regulation to the development of a specific conflict. Zbirnik naukovyh prac: Philosophy of Sociology, Psychology. Prykarpatskogo National University of imeni Vasily Stefanik. 2008; 13 (2): 182-189.

Лисенко-Гелемб'юк КМ. Психологічний вплив саморегуляції на розв'язання міжособистісного конфлікту. Збірник наукових праць: філософія соціологія, психологія. Прикарпатського націо- нального університету імені Василя Стефаника. 2008; 13 (2): 182-189.

11. Lokteva SA. Personality development and adaptation in the student environment. Naukovyy chasopys NPU imeni M.P. Drahomanova. Seriya №12. Psykholohichni nauky. 2009; 24 (48): 78-82. Локтєва СА. Розвиток особистості і адаптація в студентському середовищі. Науковий часопис НПУ імені М.П. Драгоманова. Серія №12. Психологічні науки. 2009; 24 (48): 78-82.

12. Makarchuk NO. Psychological characteristics of intrapersonal conflicts in the student age and their dynamics. Naukovyy chasopys NPU imeni M.P. Drahomanova. Seriya 12. Psykholohiya. 1 (25): 295-302.

Макарчук НО. Психологічні характеристики внутрішньоособистісних конфліктів в студентському віці та їх динаміка. Науковий часопис НПУ імені М.П. Драгоманова. Серія 12. Психологія. 2004; 1 (25): 295-302.

13. Pierceall EA, Keim MC. Stress and coping strategies among community college students. Community College Journal of Research and Practice. 2007; 31: 703-712.

14. Sasaki M, Yamasaki K. Stress coping and the adjustment process among university freshmen. Counseling Psychology Quarterly. 2007; 20: 51-67.

15. Shapar WB. Psychological explanatory dictionary. Kharkiv: Flag; 2004. 639 p.

Шапар ВБ. Психологічний тлумачний словник. Харків: Прапор; 2004. 639 с.

16. Shult CA, McIntosh JL. Employing computeradministered exams in general psychology: Student anxiety and expectations. Teaching of Psychology. 2004; 31(3): 209-211.

17. Turchak OM. Situations of emotional stress in students' learning activities. Visnyk Kharkivs'koho natsional'noho pedahohichnoho universytetu imeni H. S. Skovorody. Psykholohiya. . 2014; 47: 180-189. Турчак ОМ. Ситуації емоційної напруги у навчальній діяльності студентів. Вісник Харківського національного педагогічного університету імені Г. С. Сковороди. Психологія. 2014; 47: 180-189.

\section{Інформація про авторів:}

\section{Ляшенко Валентина}

http://orcid.org/0000-0003-2864-2219

Київський Університет імені Бориса Грінченка, Київ, Україна

v.liashenko@kubg.edu.ua

\section{Гацко Олена}

https://orcid.org/0000-0002-7275-3963

Київський Університет імені Бориса Грінченка, Київ, Україна

o.hatsko@kubg.edu.ua 


\section{Гнутова Наталія}

https://orcid.org/0000-0002-1756-6479

Київський Університет імені Бориса Грінченка, Київ, Україна

n.hnutova@kubg.edu.ua

Отримано: 05.06.2019;

Прийнято 19.06.2019; Опубліковано: 28.06.2019. 